\title{
Beauty Product Advertisements: A Critical Discourse Analysis
}

\author{
Kuldip Kaur ${ }^{1}$, Nalini Arumugam² \& Norimah Mohamad Yunus ${ }^{1}$ \\ ${ }^{1}$ Academy of Language Studies, Universiti Teknologi MARA Melaka, Alor Gajah, Malaysia \\ ${ }^{2}$ Academy of Language Studies, Universiti Teknologi MARA Shah Alam, Shah Alam, Malaysia \\ Correspondence: Kuldip Kaur, Academy of Language Studies, Universiti Teknologi MARA Melaka, KM 26, \\ Jalan Lendu, 78000 Alor Gajah, Melaka, Malaysia. E-mail: kksekhon@melaka.uitm.edu.my
}

Received: December 17, 2012 Accepted: January 11, 2013 Online Published: February 28, 2013

doi:10.5539/ass.v9n3p61 URL: http://dx.doi.org/10.5539/ass.v9n3p61

We thank Universiti Teknologi MARA for the Excellence Grant to fund the research and publication. This is very encouraging and inspiring for the researchers to publish further.

\begin{abstract}
This study examined beauty advertisements in local English magazines from a Critical Discourse Analysis perspective. This study mainly focused on the use of language in beauty advertisements and strategies employed by advertisers to manipulate and influence their customers. The analysis is based on Fairclough's three-dimensional framework. It demonstrates how the ideology of 'beauty' is produced and reproduced through advertisements in popular local women's magazines. A qualitative research was conducted on beauty product advertisements in two popular local women's magazines, Cleo and Women's Weekly. The findings indicated that advertisers used various strategies to manipulate women. The advertisements promote an idealised lifestyle and manipulate readers to a certain extent into believing whatever that is advertised is indeed true. This study revealed how the ideology of beauty is constructed and reconstructed through magazines by stereotyping how beauty products are synonymous with a better life. Advertising language is used to control people's minds. Thus people in power (advertisers) use language as a means to exercise control over others.
\end{abstract}

Keywords: CDA, advertisements, power, manipulate

\section{Introduction}

The stiff competition in attracting potential customers has forced advertisers to employ vigorous advertising strategies techniques such as, construct a problem that can only be solved by using their products. Similarly, beauty product companies advertise their products to convince women. Magazines are a good example of a powerful media which regularly reach a vast number of women. The local English Language magazines are constantly flooded with beauty product advertisements. Some of them provide quite a lot of information such as, the background of the product, its effectiveness, feedback or testimonies by celebrity's or women who have used the product, price, and so on whereas some are rather short and condensed. These advertisements tend to manipulate readers to a certain extent into believing whatever that is advertised is indeed true.

The major stakeholders in advertising are the manufacturers, consumers and advertising agencies. Advertisements reach out to consumers through various media such as internet, radio, television, magazines and newspapers. In order to ensure that advertisements are able to reach the target group, advertisers need to select the right medium. For instance, if the target group is the generation Y group, then internet would be the best source as many young people today go online when purchasing products be it clothes, gadgets, books and so on. As print media such as magazines can reach both young and old alike, advertisers or manufacturers of products take opportunity to promote their product through this media. Visuals and language in the advertisements play a pertinent role to attract women. The next section will discuss on the role of language in advertising.

Cook (2001) points out that advertisements inform, persuade, remind, influence and perhaps change opinions, emotions and attitudes. In other words, his contention is that advertisements do not only sell products but change society and make people buy things they do not want or need. He also feels that advertisements do give warnings or information to people. Hence, advertisements can help create awareness, construct identities and attitude.

There are many advertisements in women's magazines that advertise beauty products influencing women and 
beauty has become an absolute religious imperative for women, thus pressuring them to do their best to hold their beauty (Baudrillard, 2005). The "ideal" women is stereotyped through visual and textual aspects of the advertisements. Advertisers use visual and linguistic means to persuade their audience. It is argued that "advertising is the most influential institution of socialisation in modern society" (Jhally, 1995). This scenario has brought into perspective on how people who are in control of advertisements manage to exercise their power and at the same time manipulate women's beliefs. Lau and Zuraidah (2010) perceived that advertising has been subtly distorting reality and manipulating consumers to make them buy a way of life as well as goods. Thus studies on advertisements in women's magazines would be of great relevance to advertisers. In order to know how advertisers influence women, it is necessary first to understand what advertising is all about.

Advertisements are important but not many studies have been conducted in the local context from a CDA perspective. Thus there is indeed a need for studies to investigate the use of language and other semiotic modalities in beauty product advertisements. The findings of such research efforts can contribute further to the field of advertising as well as language and society.

This study will address the following research questions:

1) What are the linguistic features used in beauty product advertisements?

2) What are the discursive techniques employed in beauty product advertisements to manipulate women?

\section{Methodology \& Theoretical Framework}

The theoretical framework employed in this study is Critical Discourse Analysis framework (2001). Advertisements are seen as media discourse as they involve language and social processes. Hence this framework is used to show the link between the nature of social practice and the properties of language "texts".

A qualitative design was adopted for this study. A qualitative study was appropriate in this study which seeks to investigate how discourse in advertisements involves people's construction of meanings. Beauty product advertisements in English Language local magazines were analysed. Hence for a descriptive analysis, a qualitative analysis is more appropriate rather than a quantitative analysis. Purposive sampling was done as the study was to investigate only on beauty product advertisements where not many studies have been conducted namely lipstick, mascara and eye cream.

Data was collected from two local women's magazine, Cleo and Women's Weekly from six issues consecutively from January to June 2012. Every advertisement on eye cream, lipstick and mascara from these magazines was retrieved and analysed. The data analysis is based on Fairclough's Critical Discourse Analysis framework (2001). Hence this framework is used to show the link between the nature of social practice and the properties of language "texts". His three-dimensional framework includes a conception of discourse as text (micro level), discourse practice (meso level) and sociocultural practice (macro level). Its aim is to explore the relationships among language, ideology and power and to find out how advertisers persuade the women to buy their products. Thus, this study focused on analysing the linguistic features of beauty product advertisements in women's magazines in Malaysia and highlights how the use of language tends to manipulate women beliefs based on the content of the advertisements.

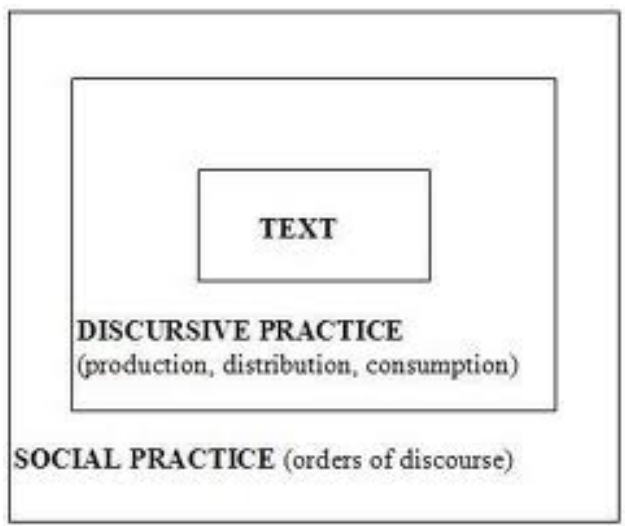

Figure 1. Fairclough's three-dimensional model, 2001 


\section{Results and Discussions}

The analysis is presented at the textual (micro), discursive practice (meso) and social practice (macro) level based on Fairclough's (2001) CDA framework.

\subsection{Textual Analysis}

The textual analysis relates to research question 1 on the linguistic features in the advertisements analysed. At this level of analysis the linguistic features such as vocabulary, syntax and rhetorical devices employed in advertisements are discussed.

In the study there was a great use of direct address in the advertisements for both ideological and practical reasons. The use of the second-person personal and possessive pronouns such as 'you' and 'yours' seek to address the readers directly and personally. When people are addresses individually rather than as part of mass audience it is considered highly valued. This handling of people on an individual basis is referred as 'synthetic personalization' (Fairclough, 1989:62). Based on the total fifty eight beauty products advertisements analysed, twenty had used direct address. Examples are as shown below:

- Because you're worth it. [L'Oreal - Cleo,March 2012]

- Lush fullness. Lashes are so perfectly satisfied...they finally deserve the throne. That aura and that beauty...it is yours. You are the king of all kings [Majolica Majorca - Cleo,March 2012]

- Specially formulated for the delicate eye area, the Restore Anti-aging Eye Creme gives you younger looking eyes... [Nutrimetics - Women's Weekly, May 2012]

- They feel airy-light on the lip...make this your new perfect daytime gloss. ...you get the subtlest of shine... [Chanel - Women's Weekly, June 2012]

In addition advertisements also need to persuade readers to buy or take certain actions. Thus advertisements usually use imperatives. The following are the examples of imperatives used in the advertisements analysed in this study.

- Get intense. Don't get heavy. Let the colour do the talking [Max Factor Lipstick]

- $\quad$ Try Guerlain Shine Automatique Lipstick [Guerlain Lipstick]

- In just 3 hours, get anti-ageing results that our other eye creams give you in 4 weeks [RoC Eye Cream]

- See the dramatic results with your own eyes [Shisedo Eye Cream]

- Get it! [Avon Lipstick]

In the advertisements there are also questions imposed to the readers to create a personal relationship by simulating informal conversation with the readers to engage them rather than merely conveying information of the product. The advertisements in this study also contained questions such as:

- Want it? [Avon Lipstick]

- Why just color when you can shine? [Avon Lipstick]

- Did you know that bagatelle means "light, musical composition" in French and that pettilant means slightly sparkling? [Chanel Lipstick]

By using questions and imperatives the advertisers are trying to establish a closer relationship with the readers. Such informality can signify equality between advertisers and readers.

Another type of strategy to simulate conversational style is the use of disjunctive syntax, that is, sentences without verbs or subjects. These sentences consist of one or two grammatical items only. Examples from advertisements in this study are as shown in the table below. 
Table 1. Disjunctive syntax in advertisements

\begin{tabular}{lll}
\hline No & \multicolumn{1}{c}{ Example in Texts } & \multicolumn{1}{c}{ Type of Advertisement } \\
\hline 1. & Volum' Express & Maybelline Mascara \\
2. & Exclusive Flex-Polymer Technology & L'Oreal Mascara \\
& Aqua Flex Base & \\
3. & Serum Enhanced & Dior Mascara \\
4. & Fiber-rich Formula & Silky Girl Mascara \\
& Vitamin E Derivative & \\
5. & Voluptous Care & Dior Lipstick \\
6. & Full Brilliance & Shisedo Lipstick \\
8. & Buttery Balm & Revlon Lipstick \\
\hline
\end{tabular}

Vocabulary is the means for advertisers to express ideological opinions about people and events. Adjectives are pertinent in advertising as they convey a positive or negative affective meaning (Delin 2000:133). Affective meaning will display reader's positive or negative evaluation of an item shown. The advertisements in this study contained adjectives with both positive and negative connotations. The positive adjectives are related to the qualities of the product whereas the negative adjectives are linked to the problems which existed prior to using the products or due to not using the problem. Below are examples of adjectives used in the beauty product advertisements.

\section{Positive Adjectives:}

anti-ageing, fabulous, ultra-lengthening fibres, smudge proof, water proof, lengthened lashes, limitless length, unbeatable thickness, lush fullness, maximum volume, wide-eyed, tiny, voluptous, light weight, natural feel, dramatic, moist, soft, advanced, smudge-shield, light-reflecting, long lasting, smudge-resistant, superlight, superfine, curlier, longer, fiber-rich, glossy, moisturizing, rich, vibrant, weightless, lightweight, softer, smoother, hydrated, airy-light, subtlest of shine, blooming, satiny, smoothen, wrinkles-resist, powerful, cell regeneration, hydrating, calming, protective, anti-inflammatory, youthful-looking, fast penetrating, younger-looking, anti-wrinkle, anti-dark circles.

Negative Adjectives:

damaged eyelashes, chapped [lips], wrinkles, puffiness, dark circles, advanced-stage wrinkles, sagging eye bags, crow's feet, free radical damage, crepey lids, saggy eye skin, age-hollowed, droopy lids, sensitive skin, sunburn.

The ways the positive adjectives are used, illustrate the positivity of the product. This will be inserted in the mind of readers which Cook refers as 'fusion' that will imbue the characterless product with desirable qualities' (2001:108). The positive adjectives are used to highlight certain qualities and values to the ideal woman. In short, the use of emotive adjectives or adjectival phrases can stimulate fantasy, dreams and desires.

Apart from adjectives, compound words are used in the beauty product advertisements.

Example:

short-lashed, fanned-out, wide-eyed, obelisk-shaped, smudge-shield, long-lasting, smudge-resistant, dual-textured, light-reflecting, airy-light, advanced-staged, age-hollowed, youthful-looking, high-performance, age-defying.

In terms of formality, most of vocabulary in the advertisements comprises a mixture of formal and informal words. Another important means to express ideological meanings in text is grammar. The types of verbs used, tenses, active or passive sentences, parallelism, pronouns, modality, nominalizations have an important function in representing 'reality'. There are repetitions through synonyms or near synonyms and parallelism which intensify meaning of the advertisements. For example, in this study synonyms such as 'restore' and 'rejuvenate'. Parallelism which is repeated use of similar grammatical structures is another device in the advertisement. The followings are examples of parallelism evident in the advertisements analysed:

- No animal derivatives. Alcohol free, mineral oil free, fragrance free, colorant free. 
- Eye Contour Lifting Serum. Reduces sagging eye bags. Lifts droopy lids. Firms eye contours. $\underline{\text { Reduces }}$ visible wrinkles and crow's feet.

- Plantscriptions anti-aging eye treatment visibly helps repair the four visible signs of eye aging including diminishing the appearance of crow's feet, reducing under eye cross hatching, smoothing crepey lids and lifting and firming saggy eye skin.

- Reduces puffiness in the eye lid, Reduces eye bags, Reduces dark circles, Reduces wrinkles around the eye.

Modality is also evident in the advertisements as shown below:

Avocado oil is highly recommended for those ...as it can help stimulate the growth of new skin cells ... can also help alleviate the pain of sunburn.

It contains numerous vitamins, amino acids and essential fatty acids that could help slow the skin's aging process!

The sentences in the advertisements are simple and declarative type. The tenses used are mainly present tense. There are also future tenses where suggestions or recommendations are given on the benefits of using the product. In addition most of the sentences in the discourse are active sentences. However, passive voice is also used in the advertisements as shown below:

1) With anti-ageing and moisturising ingredients like Vitamin E, cocoa and shea butters, the sensitive area is nourished and moisturised

2) Wrinkles, puffiness and dark circles are visibly reduced

The use of pronouns in advertisements helps create a friendly atmosphere to persuade the audience. Women will easily accept a product if a good friend recommended them. Hence advertisements that seem to talk with friends bring the readers closer. In the beauty advertisements in this study, it was found that the most common pronoun used is "you", "your", "we" and "I". The use of first and second person pronoun seems to indicate as if the advertiser is making promises that are sincere and honest. The use of personal pronouns establishes a certain type of relationship between the advertisers and the readers (Smith, 2004). For example, the pronoun "we" is regarded as authoritative and implies power while "you" reflects a personal engagement as the reader is addressed directly. In addition, the use of "our" does reflect a certain "us" versus "them" feel to it. Examples of pronouns in the beauty product advertisements in this study are:

- We have heard about the benefits of oils such as argan, olive and macademia. [Ad for eye cream]

- The skin recover its optimum activity ...

- It contains numerous vitamins ...

- ... give you beautiful soft skin

- With just one glide, her lips transform into glass-like structure to complement her elegance

- Her Pure Glossy Lipstick, the one beauty accessory that makes her shine from within

- Draw attention to your lips

- This season write your own rules with our extended line of 5 new intense pigment lip tint pens

- Lashes are 2 x more visible with our exclusive spoon brush and our formula with Pro-Keratin Fiber leaves no gap unfilled

- Maybe she's born with it. Maybe it's Maybelline

Advertisement can be categorized as 'reason advertising' and 'tickle advertising' (Bernstein, 1974). Reason advertising is direct and appeal to reason. The reason equals fact, clinical truth and needs unlike tickle advertisements which equal emotion, imagination and desires. As most beauty product advertisements are reason advertisements, conjunctive adjuncts are used in the text. According to Halliday (1994:36) the main types of conjunctive adjuncts in reason advertisements are as follows:

Additive: and, also, moreover, nor

Adversative: but, yet, however, on the other hand

Conditional: [positive] if ... then; in the event of; when

[negative] otherwise, if not

Causal: so; then; because; as a result; that's why; that means 
Purposive : in order to; for; to [ + infinitive]

Although all five types are common in advertising, Simpson and Mayr (2010) assert it is the conditional, causal and purposive types that form the semantic bedrock of reason texts. They claim that these adjuncts 'enhance', with the 'reason to buy' element becoming foregrounded through clear exposition of the benefits one gets upon purchasing a product.

In this study, the advertisements exhibit the conditional structure.

Example :

1) If you're a fan of the previous Lancome Hypnose mascaras, you'll love love this new editions as it gives you both a buildable base and a false lash effect [Ad for Lancome Mascara]

2) If you've ever experienced the "ouch" effect with eyelash curlers, say hello to the Estee Lauder Double Wear Zero-Smudge Curling Mascara. [Ad for Estee Lauder Mascara]

3) If you have thin lips, stay away from lipsticks with intense colours and matte finish. [Ad for Guerlain Lipstick]

Another conjunctive adjunct, the causal is also important in reason advertising. In the following examples, it shows how there is the reason-plus-result argument.

4) Short-lashed gals - rejoice! This mascara contains ultra-lengthening fibres as well as carnuba wax and olive oil to elongate and lift lashes one by one, even the shortest ones.

In the sentence 4 above, the first part is the cause and the second is the effect. It tells women with short lashes not to be worried as by using the product they will see the result. The purposive form of conjunctive adjunct is quite like the causal type but the difference is the former emphasizes on some recommended future course of action.

Example :

5) Avocado oil is also highly recommended for those with eczema or just plain sensitive skin as it can help stimulate the growth of new skin cells.

In conclusion, sentences 1-5 above show the primary motive for purchasing the product. And one of the means to do it is by using a semantic connectivity which relies on conjunctive adjuncts. The message in the reason advertisements is therefore simple and plain unlike tickle advertisements which require interpretation. The language in the advertisements is conversational and attempts to establish a personal relationship with customers.

Advertisers also use technical and scientific sounding words to attract readers. By using such words they hope to reflect an image of professionalism and advancement in technology. In order to impress the consumers, advertisers resort to scientific words and information to create an impression that they are up-to-date with technology. The followings are extracts from the advertisements in this study.

- The formula contains a camellia oil complex that not only conditions and nourishes the lashes, but also helps the mascara to stretch over each lash with greater ease

- Flex-Polymer Technology

- Aqua Flex Base

- Also contains collagen and pomergranate extract that protect and boost lips moisture

- Innovatively unique with HYDROVANCE moisturising complex

- New ROC Sublime Energy Eye with e-pulse technology

There is also scientific evidence provided to attract consumers such as:

1) Those with sensitive eyes will be glad to know that this mascara has been ophthalmologist tested and does not contain fragrance

2) In just 3 hours get anti-ageing results that our other eye creams give in 4 weeks [Clinical evaluation, 26 subjects]

3) Its anti-ageing results have also been opthalmologically tested where visibly firmer eyes were reported within 28 days

In the advertisements metaphors are also used such as :

"glass-like structure" [Lipstick Ad] 
"kisses as soft as rose petals" [Lipstick Ad]

Apart from that, the use of poetic devices such as alliterations and jingles make it easy for people to remember the brand, the product and the message. For example:

- Sexy, Soft, Sensuous, Striking. [Maybelline Lipstick Ad]

- Shiny Colour.

Buttery Balm [Revlon Lipstick Ad]

- No animal derivatives

Alcohol free

Mineral oil free,

Fragrance free,

Colorant free [Hadalabo Eye Cream Ad]

- Gloss. Glam. Glow. [Silky Girl Lipstick Ad]

The slogans and taglines too are catchy and easy to remember such as:

"Barbie-Like Eyes" [Lancome]

"Big is Beautiful", "Less is more" [Body Shop]

"Lips that shine, with killer color" [Revlon]

"Unleash your confidence" [Silkygirl]

"Because you're worth it" [L'Oreal]

"Maybe It's You. Maybe It's Maybelline" [Maybelline]

Numbers are also widely used in advertisements as shown in the findings. The following are examples as exhibited in the advertisements in this study .For example,

- Let's intensify the passion and romance with L'Oreal Paris Double Extension Curl Mascara, which gives you glamourous looking eyes with impressively curved lashes that are also up $\underline{90 \%}$ longer.

- The Shiseido Perfect Mascara Full Definition ...has a dual-textures brush that works to coat each lash ... to last $\underline{16}$ hours

- In just $\underline{3}$ hours get anti-ageing results that our other eye creams give in $\underline{4}$ weeks

All these advertisements evoke desires and construct the ideal beauty image for women. In some advertisements, the products have certain attributes that women would like to have for themselves for instance 'mesmerising eyes; big, lush lashes; superlight; superfine; natural feel; red carpet look; lips smell oh-so-kissable'. These advertisements create a false impression that if women were to purchase these beauty products they will possess these features with the help of these products. Thus the media misleads the women. The advertisements can influence women and shape their behaviour by creating a web of delusions.

\subsection{Discourse Practice Analysis}

This level of analysis involves studying the text's production and consumption, focusing on how power relations are enacted. In this study, the advertisers used various strategies in their discourse to attract consumers. The table below summarizes the strategies used. 
Table 2. Discourse strategies

\begin{tabular}{|c|c|c|}
\hline No & $\begin{array}{l}\text { Strategy Used in } \\
\text { Advertisement }\end{array}$ & Linguistic Devices \\
\hline \multirow[t]{5}{*}{1.} & \multirow{5}{*}{$\begin{array}{l}\text { Manufacturing consent } \\
\text { through implication }\end{array}$} & Nutrimetics Restore Anti-Ageing Eye Cream gives you younger looking eyes ... \\
\hline & & $\begin{array}{l}\text { Formulated with special conditions that immediately nourishes even the driest area on } \\
\text { your lips }\end{array}$ \\
\hline & & Sheer, brilliant color infuses lips with lasting moisture \\
\hline & & $\begin{array}{l}\text { It contains The Dior Black Glass pigment that is coated with light-reflecting particles to } \\
\text { give lashes a dramatic finish }\end{array}$ \\
\hline & & $\begin{array}{l}\text { With Advanced night repair eye, you'll see a reduction in the look of every sign of } \\
\text { aging around your eyes }\end{array}$ \\
\hline \multirow[t]{4}{*}{2.} & \multirow[t]{4}{*}{ Invoking inadequacies } & Wrinkles, puffiness and dark circles are visibly reduced \\
\hline & & Once sagging eye bags, dark eye circles and crow's feet appear, ... \\
\hline & & $\begin{array}{l}\text { The Clinique Lash Power Mascara was created to meet the needs of barely-there Asian } \\
\text { eyelashes }\end{array}$ \\
\hline & & DNA damage and skin aging. Now you have more control over it than you think. \\
\hline \multirow[t]{5}{*}{3.} & \multirow[t]{5}{*}{ Irrealisis representation } & Kisses as soft as rose petals. Blooming rosylips [lipstick ad] \\
\hline & & You'll definitely melt his heart with such alluring eyes [mascara ad] \\
\hline & & It's your power tool for making eyes at the hunk by the pool [mascara ad] \\
\hline & & $\begin{array}{l}\text { It's vanilla scented, and it smells good enough to eat and is guaranteed to make your } \\
\text { lips smell oh-so-kissable [lipstick ad] }\end{array}$ \\
\hline & & One drop unlocks younger looking eyes [mascara ad] \\
\hline \multirow[t]{4}{*}{4.} & \multirow[t]{4}{*}{ Positive self-representation } & $\begin{array}{l}\text { Our precision tapered brush grabs every lash individually and coats it to plump } \\
\text { perfection }\end{array}$ \\
\hline & & $\begin{array}{l}\text { With the age-defying power of our exclusive Chronolux Technology, you'll see a } \\
\text { dramatic reduction in the visible signs of ageing }\end{array}$ \\
\hline & & $\begin{array}{l}\text { Lashes are } 2 \times \text { more visible with our exclusive spoon brush and our formula with } \\
\text { Pro-Keratin Fiber leaves no gap unfilled }\end{array}$ \\
\hline & & This mascara contains ... to elongate and lift lashes one by one, even the shortest ones \\
\hline \multirow[t]{7}{*}{5.} & \multirow[t]{7}{*}{ Puffery } & All the proven repair of our \# 1 serum \\
\hline & & The one revolutionary formula millions of women can't live without \\
\hline & & Don’t Speak. Let Your Lips Talk \\
\hline & & Plump Your Lips \\
\hline & & It's proven to boost lip moisture levels by 156 percent! \\
\hline & & $\begin{array}{l}\text { The world's first lipstick with a glossy, moisturizing outer gel and a rich VIBRANT } \\
\text { CORE }\end{array}$ \\
\hline & & Electro-stimulation for the first time in a cream \\
\hline \multirow[t]{4}{*}{6.} & \multirow[t]{4}{*}{ Celebrity Endorsement } & Vivian Hsu (International Artiste) : \\
\hline & & $\begin{array}{l}\text { "Once sagging eye bags, dark eye circles and crow's feet appear, even the most } \\
\text { beautiful woman will lose her sparkle". Witness the instant results of } 2 \text { powerful } \\
\text { anti-ageing ingredients in } 1 \text { bottle. [Bio-Essence Eye Cream Ad] }\end{array}$ \\
\hline & & $\begin{array}{l}\text { Fan Bing Bing : "I love the electric colours. They sparkle at every angle [L'Oreal } \\
\text { Mascara Ad] }\end{array}$ \\
\hline & & $\begin{array}{l}\text { Emma Stone is the face for the collection, and is a fan of the Peach Parfaut Shade } \\
\text { [Revlon Lipstick Ad] }\end{array}$ \\
\hline \multirow[t]{5}{*}{7.} & \multirow{5}{*}{$\begin{array}{l}\text { Scientific Evidence/Clinical } \\
\text { Test Proof }\end{array}$} & 20 Patents Worldwide \\
\hline & & $\begin{array}{l}\text { Inspired by } 25 \text { years of groundbreaking DNA research, Estee Lauder scientists bring } \\
\text { you this high performance serum to help repair the appearance of past damage }\end{array}$ \\
\hline & & Award winning certified organic skincare that keeps it real \\
\hline & & $\begin{array}{l}\text { Upon } 1^{\text {st }} \text { application-clinical evaluation, } 34 \text { subjects - Wrinkles less } 36 \% \text {, Eye Bags } \\
\text { less } 33 \% \text { and Dark Circles less } 21 \%\end{array}$ \\
\hline & & Based on lab test data after multiple application \\
\hline 8. & Emotive Words & $\begin{array}{l}\text { Light weight, natural-feel, dramatic darkened look, soft touch, crispy feel, passion, } \\
\text { romance, glamorous, alluring, long-lasting, exclusive, moisturizing, glossy, voluptuous, } \\
\text { mesmerizing }\end{array}$ \\
\hline
\end{tabular}


The main audience of the beauty products advertised are women. The advertisers manipulate women by giving facts about their beauty products. For example, "The Body Shop is known for using natural ingredients".

Headlines also play a part in capturing women's attention. Magazine headlines cover a various beauty themes. For example, in this study the headlines in the advertisements are "Plump Your Lips", "Full Brilliance Sheer Color", "Shimmering Rouge", "French Kiss" [Channel Lipstick], "Haute Couleur", "Oh La La! Sheer, bold tre's chic" [Laura Mercier Lipstick], "Serum Enhanced", "Double Duty", "Rotate and Roll", "Big is Beautiful", "Strong Hold", "Barbie-Like Eyes". The language in headlines such as these tends to entice and persuade.

Advertisers also use language in a way that connotes their power over beauty to overcome unattractiveness. They show their readers that that they have something more than others. It's a case of "us" versus "them". In the advertisements analysed in this study, for example in the Estee Lauder eye cream advertisement it reads "Advanced Night Repair Eye. Comprehensive anti-aging like no other formula".

The advertisements seem to insinuate that women who aspire to be beautiful should have big, expressive, sexy eyes. Their eyes should have no dark circles under them, no eye bags, lashes should be long, full, luscious, silky and soft. In addition, fashion magazines are the propagandists who provide flattering images of celebrities (Moeran, 2009), They invite their readers to a dream world of fantasy with phrases like "Lets intensify the passion and romance with L'Oreal Paris Double Extension Mascara which gives you glamorous eyes", "Get the Red Carpet Look. So Electrifying. L'OR ELECTRIC". The use of positive self-representation is evident when the advertisers claim their product provide benefits. The contention is their product is better than others. By articulating the benefits of their products, advertisers are manufacturing consent.

\subsection{Social Practice Analysis}

This level of analysis explains the broad societal currents affecting advertisements. This level of analysis is also concerned with intertextual understanding that helps to understand the broad societal currents that are affecting the text being studied. This includes views on beauty by people worldwide and specifically Malaysian women's position within these practices. The beauty myth dates back to the past where women then had also used various traditional products to enhance their appearance. For instance, women in the olden days painted their faces used mud, clay, herbs, leaves, flowers and so on. In today's world beauty and physical attractiveness are emphasised as desirable and admired. Cosmetics or beauty products are used by women to enhance their physical appearance. The issues concerning women today such as having smooth skin, a slim body, fair skin and beautiful appearance has led to the cosmetics industry as one of the fastest growing industry. Women today are so obsessed with looking attractive and are willing to go to great lengths to achieve their desires. Beauty products advertisements are able to have control or power over consumers. Some women are sometimes misled in believing what is advertised is true. Society seems to value a fair, slim, attractive women more as evident from research. The people in power (advertisers of beauty products) exercise their power through manufacturing of consent.

Intertextuality occurs in advertising when advertisers use words from other discourses to attract readers such as words from science when advertising beauty products. For example, the eye cream advertisements "New RoC Sublime Energy eye with e-pulse technology...", "With age-defying power of our exclusive Chronolux Technology ..." and "Flex-Polmer Technology..." in a mascara advertisement. Through advertisements too identities are created. The advertisements make women feel that in order to be 'ingroup' rather than 'outgroup' they should purchase the product. They will be just like the celebrities or famous people who look good by using the product. It seems to indicate that in order to be successful one need to use products that these famous women use. Research shows that attractive people have an advantage over less attractive people. The notion is that attractive women are more successful in business and personal lives (Godoy et al, 2005). Thus women are made to feel so concerned about their appearance. They are made to feel that having good appearance is very essential.

In addition, the images of attractive models in advertisements lower the self-image of consumers. However a feeling of relief is also associated with the product advertised as it claims that the problem can be solved through consumption of the product. In other words advertisers evoke feelings of dissatisfaction among consumers themselves as a strategy to stimulate consumers to buy their products to improve their looks and eventually be satisfied. A related study by Trampe et al (2011) shows how beauty product advertisements lower female consumers' self-esteem. They assert that the advertising industry has the power to transform mundane objects into highly desirable products. Eye cream, mascara and lipstick are beauty enhancing products which once advertised affect how women view themselves. Their contention is that beauty product advertisements do not just sell products but also the lifestyle that inherently comes with using the product. Apaolaza-Ibanez et al (2011) claim that cosmetics advertising works by lowering women's self-perception and then delivering relief from this negative feeling as an emotional benefit through the brand. 
In conclusion, advertisers not only promote their products but outlines societies standards of beauty, cultural values and lifestyles today. To a certain extent the social practice has shaped the beauty ideology of Malaysian women.

\section{Conclusion}

Based on the data analysis of the advertisements, it can be concluded that advertisers use various linguistic devices such as direct address, positive vocabulary, headlines, and catchy slogans to attract women. In addition, the vocabulary used in the beauty product advertisements in this study are ideologically contested. Such vocabulary carry certain ideology of what constitutes beauty such as having less wrinkles or 'free wrinkles' eyes or lips that are 'plumped' or eye lashes that are double in length or thicker. The advertisements portray what a beautiful women as one with certain features such as long lashes, no wrinkles around the eyes, lips that shine and so on. Advertisements that appear in magazines show how one should look in order to be acceptable as part of this ideal woman. Use of direct address or pronoun "you" carry certain message that the customer is of utmost importance. Thus consumers can be influenced directly towards the product. Intertextuality also occurs in advertising when advertisers use words from other discourses to attract readers such as words from science. Hence another way to attract customers is the use of technical words. Technical words in advertisements helps convince the reader that the product is of value. The technical vocabulary reflects expertise which is the source of power. Furthermore, the use of scientific information in the beauty product advertisements reflects authority. The scientific information or words can be a way to convey expertise, which in other words reflect power.

In this study, advertisers highlight how their products are solutions to women's problems. For instance, by using eye cream it can help alleviate crow's feet, eye bags, dryness and dark circles problems. The manufacturing of consent and invoking inadequacies techniques employed dupe women. Moreover, the use of models or well-known local or international celebrities is also another technique in manipulating women. These celebrities seem to reflect power over others and are successful. The ideology of power is depicted by the celebrities in the advertisements. Every woman would like to look beautiful and attractive as reflected in the images in the magazines. The testimonies by local and international celebrities help endorse a product. Positive self-representation too is a technique employed to attract consumers in order to show them how they can benefit from the product. Most of the advertisements are open with direct benefit to the readers as evident from the findings of this study.

Based on the data analysis, it can be summarized that the most obvious theme in the advertisements is the ideal appearance or look for women. The findings indicate that women will look more beautiful with wrinkle free eyes, long eye lashes, plumped shiny lips and so on. Advertisers use various strategies to manipulate women to purchase their product. Their positive self-representation is evident when they claim their product provide benefits. The advertisers have the means to promote ideal standards of beauty. Women, the main consumers of beauty products consciously or subconsciously are coaxed into buying the products advertised. Thus it seems it is not easy to ignore the persuasive nature of advertisements. They shape ideas of what it means to be a woman in our society. Fill (2002) believes advertisements can influence consumers to purchase a product that they have never used before. They urge women to care for their appearance by recommending products that could help achieve a perfect complexion.

Globalization has impact all aspects of our lives. The view of beauty too has evolved over time. The old adage 'beauty is skin deep' may no longer be relevant as society today focuses on outer appearance. It cannot be denied that appearance can affect a women's social or career success in life. Haliza (2006) agrees that physical appearance for women is heavily subjected to social judgements. Although some people may believe that advertisements are not significant or have no effect on their values, this is far from true. Today, for instance emphasis on a thin female body and advertising creates "ultimate standard of worth, so that women are judges against this standard whether we like it or not" (Kilbourne, 1987). When constantly shown these type of images such as a slim body, perfect flawless skin and so on, it becomes normalised.

Language is a powerful tool which can shape people. People communicate through language. Magazines just like other media portray a great impact on readers as Fairclough (2002:47) aptly states that this is due to the complexity of the media discourse which presents different ideological processes. In short, advertisers manipulate women into buying a way of life.

\section{Future Research Considerations}

Future research can be conducted on other English women's magazines in Malaysia. In addition, analysis of advertisements from other media such as internet and television can be undertaken. The advertisements analysed in this study involve only three beauty products namely eye cream, mascara and lipstick. Thus, future research 
may include other beauty products as well as a bigger sample size. Apart from this, future studies need to consider a semiotic analysis of beauty product advertisements in local context.

\section{References}

Baudrillard, J. (2005). The finest consumer object: The body. In M. Fraser, \& M. Greco (Eds.), The Body: $A$ Reader (pp. 277-282). London and New York: Routledge.

Bernstein, D. (1974). Creative Advertising. London: Longman.

Cook, G. (2001). Discourse of advertising. New York, NY: Routledge.

Delin, A. (2000). The Language of Everyday Life. London: Sage.

Fairclough, N. (1989). Language and Power. United Kingdom: Longman.

Fairclough, N. (2001). Language and Power. United Kingdom: Longman.

Fill, C. (2002) Marketing Communications: contexts, strategies and applications. Harlow: Financial Times Prentice Hall.

Halliday, M. A. K. (1994). An Introduction to Functional Grammar. London: Edward Arnold.

Jhally, S. (1995). Image-based culture. Advertising and popular culture. In G. Dines, \& J. M. Humez (Eds.), Gender, race and class in media. A text-reader (pp. 77-88). Thousands Oaks: Sage Publications.

Kilbourne, J. (1995). Deadly Persuasion: Why Women and Girls Must Fight the Addictive Power of Advertising. The Free Press, New York.

Lau and Zuraidah. (2010). Fear factors in Malaysian Slimming Advertisements.

Riji, H. M. (2006). Beauty or Health? A Personal View. Malaysian Family Physician, 1(1), 42-44.

Simpson and Mayr. (2010). Language and Power. Routledge: New York. 